\title{
Comes the End of the Western Legal Tradition? - The world after Brexit, Trumpism, and the great authoritarian turn
}

HaukeBrunkhorst (brunk@uni-flensburg.de)

Flensburg University, Germany

The paper argues that the emergence of the post-world war II global order of national, international and transnational law is the final step in a long evolutionary process of modern law formation. It originates in the Papal Revolution that engendered a basic constitutional structure concerned with the solution of conflicts between emancipatory and repressive Interpretations of law, and it triggered a long-lasting co-evolution of cosmopolitan and statist legal orders (theses 1-5). This order was related to universal truth claims but now comes under threat of a post-truth democracy that is no longer democratic. Brexit, Trumpism and the new authoritarian globalization could indicate the end of the Western Legal Tradition with unpredictable but not very promising consequences (theses $6-8)$.

What actually happened?

1. The idea that the state is an invention of the $16 \mathrm{~s}$ and $17 \mathrm{~s}$ centuries Protestant revolutions, is a myth, born out of the crisis of the modern (multicultural) national state - different from the 'homogenous' nation state (Tilly) - in the first half of the 20s Century (Voegelin, Strauß, Schmitt). The Hobbesian basic assumption of German Staatsrecht from Laband and Triepel to Böckenförde and DiFabio is that the authority of the state is a conceptual and empirical presupposition of constitutional law and democracy (Möllers). When Schmitt wrote that the age of the state is over (Begriff des Politischen), he presumed with Hobbes that there are only three evolutionary stages available during the social evolution: the local state of civil war that precedes the modern state, the modern nation state as the measure of all things, and the global state of civil war that comes in the aftermath of the modern state, which operated as the great Aufhalter of the Anti-Christ, Bolshevism and Americanism. The state is legitimated metaphysically before and beyond all legal procedures of democratic legitimization. To say it with a slightly modified ("state" instead of "german people") word by Stalin: Democracies come and go, the state remains unchanged. Hegel, one of the (unvoluntary) founding fathers of the "myth of the state" (Cassirer) in early $19^{\text {th }}$ Century in his 1820 Philosophy of Right, rightly remarked that the national state (the state of the French Revolution) is only a small ship on the ocean of world history (Gans, Fine). That means that there is a great variety of centralized legal organizations of political power (states) since socially stratified societies emerged in the course of the agrarian revolution. The modern national state is just one of many, and probably not the last one. There exists an ever denser and strong new formation of inter-, trans- and postnational statist ("Staatlichkeit" vs. "Staat") organizations 
of international public law (Albert, Stichweh, Kjaer, Bogdandy) that frames and enables the further development of the national states (Thornhill). Since the end of the 19th century and early 20th century international law was professionally differentiated (Koskenniemi), state-like (in the sense of "Staatlichkeit") international organizations emerged, and the first international courts were founded.

2. The modern formation of private, public and constitutional law, political and economic corporation (freedom of corporations), statist organization, universities and science, disciplinary power, the jurist privilege in diplomacy, and even of the modern nuclear family was triggered by the first great legal revolution that was the Papal Revolution 1075-1122 (Berman, Moore, Fried). Modern society begins with the functional differentiation of a fully-fledged legal system in the 12th and 13th centuries. What I mean by "fully-fledged legal system, is an academically professionalized, and therefore autonomous legal order with a system of courts, appellate bodies, internal differentiation etc. Therefore it is no surprise that this was also the time, first, of the formation of law schools, and then of a functionally differentiated system of universities. Autonomy of science (Honnefelder) emerged together with the autonomy of law. The differentiation of the legal system enabled the beginning differentiation of religion and state, and the spheres of the sacral and the profane, even if law, religion and politics still overlapped within the statist organizations of Church and Empire, kingdoms and city states.

3. Modern constitutions are the final (but not at all necessary) result of the highly unlikely (but not unplanned) fusion of the incompatible legal traditions of canon law of universal and egalitarian salvation with Roman Civil Law that is - as all civil law - a law of coordination of the interests of the ruling classes. This dialectical fusion was enabled by a cognitive and normative learning process that accompanied the age of the Papal Revolution. It consisted in a further rationalization of Christian monotheism through platonic ontology (ontotheology) and - mediated by the Islamic reception - Aristotelian logic, which together made it possible to reconstruct the recovered collection of Roman Civil Law as a professionally rationalized system of legal text books. This was the same time when a first gestalt of the modern intellectual could be observed (Leyser).

4. The new public law was the "existing contradiction" (Hegel) of repression and emancipation. The contradiction legally was integrated through the dialectical method of Gratian's CONCORDIA DISCONCORDANTIUM CANONUM. Planned and unplanned processes came together during the revolutionary age, which shows that its legal advances were not just evolutionary advances accompanied by the false consciousness of intellectuals that we, the people have made them (Luhmann). The popular slogan of the revolution that was "Freedom of the Church" (Libertas Ecclesiae) aimed already to the most important legal and political advances of the Papal Revolution because it turned the pre-revolutionary struggles over the preservation of privileges for single churches under the slogan ECCLESIA LIBERA upside down into the revolutionary slogan LIBERTAS ECCLESIAE that refered to the future freedom of the universal church under a general concept of law (Allgemeiner Rechtsbegriff). But Luhmann (as ever) was not completely wrong. The new law was a strong instrument to stabilize the system (with all its real advances) and enhance the power of the haves and the powerful. But the plans and utopian visions also became part and parcel of the new legal system, because the same law that brought clerics and aristocrats to power could strike back (Müller). It enabled the have-nots and powerless to use the stories of the bible, which had become part of professional law and legal studies, to make a 
legal claim as the famous "When Adam delved and Eve span who was then the gentleman?" that finally became one of the slogans of a further Revolution of Protestant bonded farmers ("common men").

5. The basic constitutional structure of modern law established for the first time by the Papal Revolution enabled the struggle of individuals and social groups for the right and the rights from within the law. This struggle keeps within the continuum of the legal evolution even in cases of revolutionary change. For example, when Emanuel Josef Sieyés claimed at June 17 of 1789 in the Assembly of Estates, to transform the Assembly of Estates into a National Assembly, he made a selfcontradictory institutional speech act that (with a grain of salt) triggered a great revolution. But, it was a speech act not in the natural state of the woods of Paris but a legal act within the constitutional framework of the Ancien Regime - with the ironic footnote that the contradiction finally was healed by the king (Dreier). The revolutionary actors who depose or charge the king, act not beyond the law but just illegally. However, as Kant famously has argued, once they find a new republican state, and then charge the former king, they act legally, again within the law. Finally, the swelling white noise of the discourse covers the bridge between the old and the new law with arguments and justifications.

6. The establishment of a functionally differentiated legal system and the basic structure of modern constitutionalism by the Papal Revolution triggered something as a second Axis Time (Geyer). The original learning process enabled further learning processes and revolutionary changes, which transcended modern law from within ever again. Today written constitutions function as legally embodied normative constraints of legally stabilized functional adaptation and instrumental class rule. These legal constraints enable egalitarian political selfdetermination, which is comprehensive (Allzuständigkeit). However, the development of a new Axis Time might come to an end under the increasing pressure (and complexity) of disembedded global capitalism, global private law regimes, and authoritarian liberalism, which suddenly emerges everywhere around the globe. The second Axis Time that began with the legalization of Jesus speech act: "I am the Truth" seems to come to an end in the post-truth postdemocracy of Marie le Pen, Boris Johnson and Donald Trump.

7. Modern democracy is depending on the "wild and anarchic complex" (Habermas) of a diffuse and socially, culturally, politically and legally inclusive public sphere that has access to, and is fueled by a stream of hypothetic and post-conventional empirical and practical knowledge, produced by specialized scientific, philosophical, legal, aesthetic and theological discourses, which are open to and driven by rational criticism and revision. The state of the art of expert cultures must be available for the selective perception, needs and options that are the basis of will formation in the public struggle over the generalizability of material and ideal interests of social groups, classes and individual human beings. During the last 30 years (to say it very oversimplified) the strongly monopolized new global media- and cultural-industry, based on the technical innovations of the internet and private interest of profit, has shaped a global public that has transformed the selective access of the wild and anarchic complex of the public sphere to the same state of the art of expert cultures into a completely fragmented public that blocks access of rapidly growing parts of the population to the same state of the art of expert cultures. Instead, the new media- and cultural industry replaced the latter by a huge variety of socially and technically constructed fake news, mythical obscurantism, blatant lies, rapidly mobilized 
resentments, hate speech cascades, and (mostly racist) prejudice, engendered rapidly and reinforced strongly by the echo chambers of the internet (Sunstein). "The more senseless the antagonism, the more rigid the blocs." ${ }^{1}$ The simple (hypothetical but empirically well backed) knowledge of normal science (concerning e.g. climate change and evolution) successfully has been transformed by the fragmented public opinion into the clash of fundamentalist statements of faith. Social science access to public discourse has been blocked completely and replaced by micro-economics with a highly selective relation to social reality, mathematically perfect macroeconomics with a completely counterfactual relation to social reality, individualizing and atomizing cognitive psychology, neuro-science, a selective reception of evolutionary theory that is in accordance with lifelong education for competitiveness, and so on. ${ }^{2}$ Information ("content") for all the different and culturally diverse groups and regions now is sold on the content-online-markets together with the social construction of a neatly fitting social, cultural, economic and political reality, in the words of Matthias Döpfner, chief executive of the Axel-Springer AG: "Content is our top priority." ${ }^{3}$ Theories of social, cultural and media radical constructionism are deeply wrong with their absurdly idealist thesis, that reality is a construction but, as the century old sociological Thomas-theorem puts it: "It people define situations as real, they are real in their consequences." And the consequences of fake-reality are deadly now, and - by the way - together with the emergence of a global youth culture of highly educated masses of no future generations also explain most of fundamentalist mass-killings. This makes it possible everywhere that leaders, such as Donald Trump, are elected with less than a quarter of eligible voters, and democratic constitutions, as in the Brexit, are destroyed by little more than a third of the voters through factually irreversible suicide-referenda, which are close to illegal, and therefore, hard cases for the courts who come too late anyway (Offe). "A post-truth democracy would no longer be democratic," Habermas already wrote after the invention of embedded journalism in the BushBlair Gulf-War. All journalism now is embedded journalism - in a world of marketembedded states. ${ }^{4}$

8. The global constitutional system that emerged after the Second World War, and led to the transnational constitutionalization of national states (Thornhills paradox) was a strong further progress within the path laid by the Papal Revolution that had put in place the co-evolution of national states and cosmopolitan institutions (Albert, Brunkhorst, Thornhill). The productive paradoxy of transnationally constitutionalized national states that was the last step of this long lasting co-evolution, has been transformed through 40 years of neoliberal transformation from state-embedded markets to market-embedded states (Scharpf, Streeck) into a co-evolution of highly integrated transnational

\footnotetext{
${ }^{1}$ Max Horkheimer/ Theodor W. Adorno, Dialectic of Enlightenment, Stanford: Stanford University Press 2002, 169.

${ }^{2}$ In a curriculum for a graduate school in social, cultural, economic, legal and political sciences at Gießen University you can find the following (different!) course offers and workshops: career service, projektmanagement, effizient lessen, führungskompetenz, moderationstechniken, zeitmanagement, grant writing, academic writing, grand writing advanced, bewerbungstraining, berufstraining, selbstmarketing, grand writing advanced, conference chair training, happy career days.

${ }^{3}$ See: Nicola Clark, “An Old-Media Empire - Axel Springer Reboots for the Digital Age”, New York Times, 20.12. 2015; "Speech held by Mathias Döpfner at the German Newspaper Congress on September $26^{\text {th }}$ in Berlin", Bundesverband Deutscher Zeitungsverleger, Pressemittteilung 26. 9. 2016, http://www.nytimes.com/2015/12/21/business/media/anold-media-empireaxel-springer-reboots-for-the-digital-age.html? $r=0$ (24.11.2016).

${ }^{4}$ Jürgen Habermas, „Religion in der Öffentlichkeit“, in. Habermas, Zwischen Naturalismus und Religion Frankfurt: Suhrkamp 2005, 119-154, hier: 150f, my translation.
} 
technocratic order and deeply fragmented national states, which has exhausted the resources of democratic solidarity (Plaßmann). We have now a crisis of legitimization on both levels, the national and the transnational, and the paradigmatic case is the European Union. The crisis could be solved only through a democratic method of CONCORDIA DISCONCORDANTIUM CANONUM that works on both levels. Unfortunately, as it seems, there is no such solution available. If the fragmented national states progress to decouple themselves from transnational law, the suicide-referenda will work and fragment them further, and in shortest time they will become an exact copy of the structure (not the uniforms) of the Behemoth, explained by Franz Neumann at the beginning of World War II in Europe. Welcome back to the 1930s.

Reading List

At thesis 1:

Charles Tilly, European Revolutions 1492 - 1992 . Oxford: Blackwell, 1995.

Matthias Albert/ Rudolf Stichweh, Weltstaat und Weltstaatlichkeit, Wiesbaden: VS 2007.

At thesis 2:

Harold Berman, Recht und Revolution, Frankfurt: Suhrkamp 1991 (English original: Law and Revolution 1982).

At thesis 3, 5, 6:

Hauke Brunkhorst, Critical Theory of Legal Revolutions - Evolutionary Perspectives, New York: Bloomsbury 2014.

At thesis 4:

Johannes Fried, Hg., Die abendländische Freiheit, Siegmaringen: Thorbecke 1991

Friedrich Müller, Wer ist das Volk? Eine Grundfrage der Demokratie, Elemente einer Verfassungstheorie VI . Berlin: Duncker \& Humblot 1997.

At thesis 7:

Claus Offe, Europa in der Falle, Berlin: Suhrkamp 2016

Brunkhorst, Selbstbestimmung durch deliberative Politik, Leviathan 1/ 2017 (forthcoming).

At thesis 8:

Franz Neumann, Behemoth. The Structure and Praxis of National Socialism, Oxford: Oxford University Press 1944. 